\title{
РЕАЛІЗАЦІЯ СТРАТЕГІї ЗДІЙСНЕННЯ ВПЛИВУ В КОНСТРУКЦІЯХ ЗІ ЗНАЧЕННЯМ ПРЕФЕРЕНЦІЙНОСТІ
}

\author{
ПОЛІНА ТКАЧ \\ Академія внутрішніх військ МВС України, Харків - Україна \\ REALIZACJA STRATEGII WYWIERANIA WPŁYWU \\ W KONSTRUKCJACH ZE ZNACZENIEM PREFERENCJI
}

\author{
POLINA TKACZ
}

Akademia Wojsk Wewnętrznych MSW Ukrainy, Charków — Ukraina

STRESZCZENIE. Treścią artykułu są warunki realizacji strategii wpływu w werbalnych konstrukcjach z semantyką preferencji takich chwytów taktycznych, jak prośba, porada, oferta.

\section{REALIZATION OF THE STRATEGY OF INFLUENCE ACCOMPLISHMENT IN CONSTRUCTIONS EXPRESSING PREFERENCE}

\author{
POLINA TKACH \\ Academy of Internal Troops of the Ministry of Internal Affairs of Ukraine, \\ Kharkiv - Ukraine
}

ABSTRACT. The article focuses on the conditions of the realization of influence in constructions expressing preference. Peculiarities of communicative structure of speech acts such as request, advice, suggestion have been revealed.

$\mathrm{M}$

ова є наймогутнішим засобом впливу, оскільки вона здатна не лише описувати явища довкілля, але й інтерпретувати їх, формуючи певну картину світу, керуючи сприйняттям тієї чи тієї ситуації та нав'язуючи іiі позитивну чи негативну оцінку. Людина використовує комунікативний вплив у всіх сферах діяльності. Саме тому сучасні наукові розвідки спрямовані передусім на дослідження прагматичного аспекту мовленнєвої діяльності людини, що передбачає виявлення способів реалізації інтенцій мовця в процесі спілкування.

Мета цієї статті — виявити умови реалізації стратегії здійснення впливу в конструкціях зі значенням преференційності.

Основною складовою процесу комунікації $є$, як відомо, іллокутивний акт, тобто реалізація інтенції мовця. На думку О. Селіванової구 бальним, осмисленим наміром мовця й, відповідно, не має мовного характеру, а своєї мовної реалізації набуває через стратегію². Отже, стратегія — це комплекс мовленнєвих дій, спрямованих на досягнення кооперативного результату, глобальних або локальних комунікативних цілей, ефективності інформаційного обміну та впливу в процесі мовленнєвого спілкування ${ }^{3}$, тобто стратегію можна

${ }^{1}$ О. О. Селіванова, Сучасна лінгвістика: напрями та проблеми, Полтава 2008, с. 605.

${ }^{2}$ Ф. С. Бацевич, Основи комунікативної лінгвістики, Київ 2004, с. 120.

${ }^{3}$ О. С. Иссерс, Коммуникативные стратегии и тактики русской речи, Омск 1999, с. 54. 
трактувати як план реалізації наміру, що виражається у виборі системи заздалегідь спланованих ходів і дає змогу комунікантам досягти своєї мети. Мовленнєві ж прийоми, тобто інструменти реалізації загальної стратегії, як відомо, називають тактиками ${ }^{4}$. Дослідники пропонують їх класифікації відповідно до специфіки процесу спілкування, проте в сучасній лінгвістиці не існує єдиної типології комунікативних стратегій і тактик. Науковці стверджують, що необхідно сформулювати теорію загальної комунікативної стратегії щодо здійснення впливу, для реалізації якої необхідно використовувати низку тактичних прийомів, що характеризуються своєрідними мовленнєвими виявами. Така стратегія відповідає провідній інтенції комунікації - переконливого впливу на співрозмовника ${ }^{5}$. Стратегія здійснення впливу передбачає наявність бажання з боку мовця змусити слухача втілити певні ідеї, що відповідають інтересам мовця. Ця стратегія характеризується використанням таких мовленнєвих актів, як прохання, порада, пропозиція тощо.

Особливості преференційної семантики, зокрема спорідненість із семантикою оптативу, зумовлюють уживання висловлень зі значенням преференційності із метою прохання, що спонукає слухача задовольнити потреби й бажання мовця, наприклад: [...Справді - жити іноді невесело, але смішно. Лише людина сміється, а значить... А! Щось я розфілософствувався]. Приїдь-но краще до нас пошвидше (І. Павлюк). Бажання мовця вибрати одну 3 альтернатив $\epsilon$ мотивом для того, щоб надати перевагу саме їй, але оскільки втілення цього вибору в життя залежить від слухача або іншої особи, преференційне висловлення набуває інтенції прохання, порівн.: Я волію (хочу), щзоб ти приїхав швидше, тому прошу тебе: „Приїдь-но краще до нас пошвидше”.

Прохання передбачає певний вплив мовця на слухача (адресата) 3 метою досягнення виконання необхідної або невиконання зайвої, шкідливої, з погляду мовця, дії. При цьому мовець і слухач (адресат) можуть не залежати один від одного: [- Дивіться, як виглядає галерея]. - Ви краще покажіть на проекті частину без скла, щзо зараз монтується з іншого боку галереї (за матеріалами Інтернет-форуму). Співрозмовники є людьми однакового соціального статусу, тому висловлення прохання є цілком зрозумілим, оскільки мовцеві не подобається замовчування, до якого вдається співрозмовник, і він прагне змінити ситуацію, віддаючи перевагу наявності повної інформації. Саме рівність співрозмовників не дає змоги інтерпретувати вислів як наказ чи вимогу. Лексема краще в таких конструкціях є засобом пом'якшення категоричності вислову.

Оскільки у виконанні дії зацікавлений саме мовець, то у зверненні до співрозмовника він часто обгрунтовує своє прохання, аргументує його доцільність, необхідність, порівн.: - Не дивись, Павлусю, краще засни, - ти жс слабенький, тобі треба заснути. - Мамочко, я ще не хочу спати, мені так гаряче... Я не буду спати, краще ти мені казочку розкажи (Леся Українка). Мотивом для виконання слухачем прохання мовця є його хвороба, що потребує сну. Мотивацію для дій на прохання мовця може створювати виявлення мовцем приязного ставлення до нього, лестощі на його адресу та ін.

Вираження комунікативного наміру мовця у преференційних висловленняхпроханнях може експлікуватися за допомогою дієслів, що позначають відпо-

${ }^{4}$ Ф. С. Бацевич, Зазнач. працяя, с. 120.

5 И. В. Певнева, Коммуникативные стратегии и тактики в конфликтных ситуащиях общения обиходно-бытового и профессионального педагогического дискурсов русской и американской лингвокультур, автореф. дис. канд. филол. наук, Кемерово 2008. 
відні мовленнєві дії (просити, молити), наприклад: - [Михайло? - кинулася Меланія, аж головою затрясла]. - Ти мені краще не згадуй про нього. Прошу тебе, лише про нього не згадуй мені (І. Вільде). Мовець підкреслює бажаність того, про що просить, повторюючи своє прохання двічі.

Конструкції зі значенням преференційності використовують як засіб висловлення поради, що є повчанням, підказуванням, як діяти. Пораду розуміємо як повідомлення слухача про те, що буде для нього краще за інше, наприклад: [Якось ішов Іван від автобуса разом з Миколою Григорківим, щуо любив, як баба, всіх судити і поради давати. Ото Микола й завівся: — ... Ти хоч і дурний, вибач мені на слові, але ти часом і розумний буваєш. Видиш, дримби робиш, продаєш. Трохи таздуєи. Значить, не зовсім дурний]. То пристав би ти краще до якоїсь розумнішої молодиці, [щоби заговорила добрим словом до тебе, та обігріла тебе, а то спиш у повітиі, як пес бездомний, та ще сам їсти вариш. Нашьо тобі тота Даруся? Толку з неї для чоловіка нема ніякого] (М. Матіос). Значення преференційності в таких конструкціях передбачає дві альтернативи: одна реальна, що відображає наявні факти довкілля, інша — ірреальна, що відтворює уявлення мовця про те, яким, на його думку, він повинен бути і які дії слухача щонайбільше сприятимуть його поліпшенню. У наведеному прикладі можна побачити, що мовець і слухач (адресат) мають різні життєві пріоритети, що виражається в описі мовцем наявних альтернатив.

Ситуація поради вимагає наявності відповідного статусу як у мовця, так і в слухача (адресата), порівн.: [Складаючи букет, не намагайся його наповнити різноманіттям квітів та зелені], візьми краще 2-3 квітки - і тоді твій букет буде легкий $і$ розлогий (за матеріалами Інтернет-форуму). Мовець постає як людина поважна, впливова, іноді старша за віком, тобто людина, яка має в очах суспільства право давати поради іншим (у наведеному прикладі фахівець із обговорюваного питання). У протилежному випадку спроби мовця давати поради можуть сприйматися як нав'язливість і навіть нахабство. Відповідно слухач (адресат) - людина молода, недосвідчена або залежна від мовця. Однак основою вибору повинна бути відповідність поради світогляду самого слухача, а не авторитет мовця, адже преференційність - одне з найсуб'єктивніших значень, і вибір здійснює кожна людина виключно у власних інтересах, тому статус мовця й слухача не є доказом і мірилом дієвості самої поради.

Як було зазначено, порада завжди пов'язана з усвідомленням певної необхідності в інтересах слухача. Для того, щоб слухач сприйняв преференційне висловлення саме як пораду, мовець часто вдається до пояснень того, чому саме слухач має віддати перевагу обраній мовцем ситуації, наприклад: Екскурсії в Сгипті набагато краще (бо дешевще) замовляти в районних агентствах i кошти заощадите, $i$ в краєвидах не прогадаєте! (за матеріалами Інтернетфоруму). Мовець не має жодного особистого зацікавлення і керується лише бажанням вберегти слухача від зайвої витрати грошей, тому й радить, як цього уникнути.

Значення преференційності відіграє важливу роль у моделюванні поради, оскільки в пресупозиції поради закладено бажання мовця підказати, навчити слухача, як краще вчинити, наприклад: Bхід у підвал $і$ вихід на мансарду краще об'єднати, бо інакше буде морока з перекриттям! (за матеріалами Інтернет-форуму). За контекстом ці слова належать фахівцю з будівництва. Проте у висловленні порад мовець керується передусім власними уявлен- 
нями про те, якою повинна бути ситуація. Інтереси ж слухача, про які піклується мовець, ураховуються лише настільки, наскільки відповідають уявленням мовця, наприклад: [Якщо шумить сильно і постійно, потрібно не відкладаючи почистити та змастити його, а можливо, $і$ замінити]. Краще звернутися до фахівців, бо інакше згорить і тоді ноутбук на смітник! (за матеріалами Інтернет-форуму). Надаючи перевагу саме тій альтернативі, яку спеціаліст радить вибрати, він насправді не має жодного уявлення про бажання слухача. Спеціаліст, справді, думає, що альтернатива, яку він уважає найкращою для слухача, буде для нього більш корисною.

Можливі також контексти, коли преференційне висловлення, оформлене як порада, насправді, є прихованою погрозою через порушення відповідності між бажаннями мовця і його уявленнями про бажання слухача: Iди краще вивчи уроки, бо потім усе жсиття жсаліти будеш. [Яке в чотирнадиять років може бути кохання?!] (за матеріалами Інтернет-форуму). Репрезентуючи дію як бажану для адресата, в цьому висловленні мовець ніби надає співрозмовнику право вибору, насправді ж, він уважає висловлену альтернативу єдино можливою. Саме для того, щоб забезпечити виконання дії, мовець „радить” зробити так, як він бажає, погрожуючи слухачеві небажаними для нього наслідками (бо потім усе життя жаліти будеш). Те, що мовець радить і погрожує водночас, свідчить про мовну гру.

Прийом пропозиції характеризується тим, що мовець, уважаючи виконання певної дії доцільним, необхідним, корисним як для нього самого, так і для слухача або для іншої особи (осіб), виносить свою думку на обговорення, намагаючись переконати слухача й тим самим спонукати його виконати відповідну дію. Цей мовленнєвий акт відповідає порівняльно-оцінній природі преференційного значення, адже пропозиція передбачає введення співрозмовниками альтернативних варіантів розв'язання проблеми, кожен із учасників розмови віддає перевагу своєму варіанту, пропонуючи те саме іншим, наприклад: - [... Іноді мене мучить совість. Адже то ми привели його до влади, в тому числі й ми. Та не дивіться ви так на мене!] - Антоне, давай краще просто відпочинемо, потім поговоримо (П. Бондаренко). Мовець не наказує, не просить і не вимагає нічого від співрозмовника, він тільки пропонує, тобто запрошує співрозмовника подумати й оцінити можливі варіанти відповідей на порушені питання, змушує його замислитися над тим, як зробити краще, й показує своє бачення розв'язки проблемного завдання.

На думку А. Вежбицької 6 , у цій ситуації мовець намагається допомогти співрозмовникові прийняти рішення, привертаючи його увагу до тих можливостей, які він міг і не помітити: Я запропонував, щзо чи не краще робити меншу кількість заходів, але щзоб вони були підкріплені відповідною організаційною роботою і могли привабити глядачів. [На изе питання можна було дати дипломатичну відповідь, але міський голова сприйняв критику дуже агресивно] (Інтернет-видання „СITI”). Міський голова, бажаючи вдосконалити систему телекомунікації, пропонує свій варіант рішення проблеми. Він не має права вимагати, а лише подає альтернативу на розгляд реципієнта. Для підкреслення ненав'язливості позиції мовця використано експлікацію обраної ним тактики - використання слова „запропонував”.

6 А. Вежбицкая, Речевые акты, [в:] Новое в зарубежной лингвистике, Москва 1985 , вып. 16, с. 187. 
Для акту пропозиції не має жодного значення, які стосунки пов'язують мовця і слухача, який соціальний статус вони мають, наприклад, висловлювати пропозицію можуть члени родини, піклуючись про спільні родинні інтереси, порівн.: - Чекайте, мої дорогі, замість стільки галасу із-за паршивої газети, то чи не краще... закласти своє видавництво? (І. Вільде). Тут тітка, якій не подобається зацікавленість племінниць газетами, які вона не схвалює (йдеться про газети $20-\mathrm{x} \mathrm{pp.} \mathrm{XX} \mathrm{ст.,} \mathrm{де} \mathrm{панували} \mathrm{комуністичні} \mathrm{ідеї,} \mathrm{що} \mathrm{ще} \mathrm{не} \mathrm{були} \mathrm{попу-}$ лярні в Західній Україні), пропонує створити власне видавництво, щоб відволікти їх від захоплення шкідливими, на їі думку, ідеями.

Пропозицію можуть вводити сторонні люди, зацікавлені або не зацікавлені в їі втіленні, наприклад: - [Демиде, людина ти явно печерна, але мені подобаєшся, а значить, не пропадеш... - Я $і$ без тебе не пропаду]. - А може, краще пропадати зі мною? - [У голосі Лілі почулася лукава нотка] (В. Собко). Висловлення дівчини можна зрозуміти як пропозицію зав'язати стосунки, що підкріплена попереднім зізнанням про те, що хлопець їй подобається. Пропозиція у формі питання є досить поширеною й відповідає ненав'язливості, некатегоричності цього мовленнєвого акту.

Отже, прагматичний аналіз преференційних висловлень засвідчив, що вони $\epsilon$ одним із виразних засобів реалізації стратегії здійснення впливу. Інтенція таких висловлень виявляється в здійсненні суб'єктом преференції впливу на адресата. Відповідно до цього суб'єкт удається до мовленнєвих актів прохання, поради, пропозиції, що мають свої комунікативні особливості, зокрема акти поради й пропозиції, орієнтовані передусім на дотримання (інколи вдаване) інтересів слухача, тоді як акт прохання спрямовано на здійснення впливу в інтересах мовця. 